\title{
Los fuertes fronterizos chilenos. Resistencia e interacción en la frontera de Chile en los siglos XVI y XVII
}

\author{
Ricardo Alonso de la Calle \\ Instituto Nacional de Estadística, Madrid
}

\begin{abstract}
The Chilean frontier forts. Resistance and interaction in the border of Chili during the Sixteenth and Seventeenth Centuries
\end{abstract}

RESUMEN

Durante los años de su conquista y colonización, e incluso en el período republicano, el territorio chileno fue un espacio que marcó como ningún otro de la América hispana los rasgos del fenómeno fronterizo. Las peculiares circunstancias de su ocupación forjaron una tipología humana ciertamente singular, el hombre de frontera, una figura que hizo de la transgresión de las normas de su sociedad de origen una pauta de vida. Las condiciones en las que se desarrolló la ocupación de Chile determinaron que la actividad colonial girara en torno a los fuertes fronterizos, centros militares en los que se concentró el intercambio de especies entre indígenas e hispanos. Los contactos, unas veces violentos y otras pacíficos, entre las diferentes sociedades propiciaron, a la larga, un proceso de mestizaje que pone en entredicho el enfrentamiento denodado entre dos grupos antagónicos que nos han querido hacer ver las crónicas indianas.

PALABRAS CLAVE: Chile / frontera / fuertes / siglos XVI y XVII

\section{ABSTRACT}

During the years of the Conquest and Colonization and even during the Republican period, the Chilean territory showed, rather than any other Spanish American, the features of the frontier areas. The special circumstances of the Spanish settlement created a peculiar human typology: the frontier man, whose standard of life involved the permanent transgression of every rule (political, social or religious) of his community of origin. This peculiarity caused that the colonial activity took place around the border forts (fuertes), military centers where the intercourse between natives and Spanish tended to concentrate. The contacts between the communities were sometimes violent, sometimes pacific, but, in the long term, they favoured the croosbreeding (mestizaje). This fact cast doubt on the image of a continuous fight between two rival groups that the American chronicles have reported to us.

KEYWORDS:

Chile / frontier / forts / 16th \& 17th Centuries 
El descubrimiento de América dio lugar al surgimiento de una nueva frontera en el horizonte medieval europeo. Con él se cerró el círculo que acotaba geográficamente el imaginario del hombre occidental, delimitado entonces por Extremo Oriente al este, por el África subsahariana al sur y por las regiones polares al norte; fronteras todas éstas de las que en mayor o menor medida los europeos tenían conocimiento desde la Antigüedad, pero inexploradas o con referencias muy difusas. En América, la amplitud del territorio anexionado y la dificultad de control por parte de la Corona española de tan vastos dominios supusieron, a la vez, el establecimiento de una serie de fronteras fluctuantes en el tiempo dentro de la gran frontera que era en sí mismo el continente. Si hemos de destacar alguna de éstas, sin duda hay que citar a la chilena, que sin haber disfrutado de la difusión popular que ha tenido la gran frontera por antonomasia - la norteamericana del siglo XIX, de la que profusamente se ha ocupado la literatura y, sobre todo, el cine- no por ello deja de ser menos fascinante.

El carácter fronterizo es el rasgo que más se ha destacado de Chile en la historiografía actual ${ }^{1}$. No en vano se ha mostrado al país transandino como el arquetipo de tierra de frontera, tanto por la singularidad y riqueza de las relaciones que se entablaron entre los que vivían a un lado y otro de la misma como por su amplitud en el tiempo ${ }^{2}$, prolongada desde las primeras tentativas de conquista, en los años treinta del siglo XVI, hasta finales del XIX, ya como república independiente ${ }^{3}$.

1 La bibliografía recalca esta naturaleza fronteriza al conceder, en los estudios sobre Chile, un tratamiento considerable a los modos de vida que impuso tal particularidad, así como un protagonismo especial a las líneas que definen su espacio geopolítico. Sobre la variabilidad de la demarcación nacional chilena, véase J. EyzAguiRRE, Breve historia de las fronteras de Chile, Ed. Universitaria, Santiago de Chile, 1967; I. VÁZQUEZ DE ACUÑA y O. CABRERA, Breve historia del territorio de Chile, Instituto de Investigaciones del Patrimonio Territorial de Chile / U. de Santiago de Chile, Santiago de Chile, 1984, y G. LAGOS CARMONA, Los títulos históricos. Historia de las fronteras de Chile, Andrés Bello, Santiago de Chile, 1966.

2 A lo largo de más de tres siglos son muchos los casos que avalan esta singularidad. Es particularmente destacable por su extravagancia, a la par que da fe de la prolongada extensión temporal de la naturaleza fronteriza de Chile, la peripecia del aventurero francés Antoine Tounens, que hacia 1860 se proclamó rey de Araucania con el nombre de Orelio Antonio I. Aprovechando la declarada enemistad de los araucanos hacia las autoridades hispanocriollas desde los tiempos de la conquista, llegó a establecer alianzas con los jefes indios y conseguir la adhesión de algunos de ellos a su causa secesionista. Redactó una Constitución, que tomó como modelo a la francesa, en la que establecía una monarquía hereditaria. Evidentemente, la peregrina aventura no prosperó, pues el gobierno chileno puso fin a los propósitos de monsieur Tounens. Las milicias chilenas lo detuvieron y fue recluido en un manicomio y luego repatriado. Véase al respecto M. T. LuIz y M. SchiLLAT, La frontera austral. Tierra del fuego, 1520-1920, SP Universidad de Cádiz, Cádiz, 1997, pp. 125-129.

3 Una vez consolidada la independencia, en 1855 se firmó un tratado de límites con Argentina que ya originó muchas controversias y debates a fines del siglo XIX. La imprecisión de los límites geopolíticos entre Chile y Argentina en Tierra del Fuego aún sigue generando disputas de cierta gravedad. De hecho, en 1978, la mediación del papa Juan Pablo Il evitó en el último momento una guerra entre ambos países por el litigio de soberanía de islas en el canal de Beagle. Estas desavenencias tuvieron su expresión más grave cuando Chile llegó a colaborar militarmente con el Reino Unido en la guerra de las Malvinas. Véase al respecto J. EYZAGUIRRE, La soberanía de Chile en las tierras australes, Zig Zag,Santiago de Chile, 1956, y G. Carrasco (ed.), Argentina y el laudo arbitral del canal Beagle, Ed. Jurídica de Chile, Santiago de Chile, 1978. Los contenciosos fronterizos de Chile no se han circunscrito únicamente al ámbito austral. Sobre las polémicas con Bolivia, véase M. L. Amusategul, La Cuestión de límites entre Chile y Bolivia, IIPTC/USC, Santiago de Chile, 1987. 
En el análisis del fenómeno fronterizo chileno son muchos los aspectos que podrían considerarse según se haga desde una perspectiva política, militar, económica, cultural o religiosa, cuando no desde todas ellas dada la complejidad que reviste. Aquí atenderemos fundamentalmente a la consideración del territorio chileno como una frontera humana - un espacio, por tanto, en absoluto vacío— donde el roce de culturas diferentes, junto con unas circunstancias determinadas, dieron forma a una tipología humana peculiar que aquí encontró su definición más paradigmática: el hombre de frontera. La lejanía del territorio chileno de los centros de poder - no ya sólo de la metrópoli, sino también de los principales centros administrativos establecidos en América - y la imagen de tierra peligrosa con la que contó, tanto en la propia América como en la Península, fueron circunstancias que propiciaron el establecimiento de un espacio donde lo ortodoxo y lo heterodoxo no estaba bien definido, un ámbito en el que la moral de la metrópoli fue transgredida en un número relativamente alto de casos cuando, unas veces forzada y otras voluntariamente, soldados, aventureros o colonos se integraron en comunidades indígenas, tomaron esposas indias, tuvieron hijos mestizos, aceptaron costumbres «bárbaras» o renegaron de los principios de comportamiento de su sociedad natal. Imagen ésta que contrasta con la otra que nos ha dibujado la tradición, en la que se muestra un enfrentamiento denodado entre dos grupos antagónicos. Esbozar un cuadro de la realidad fronteriza chilena pasa por buscar un equilibrio entre ambas imágenes ${ }^{4}$.

\section{LA CONQUISTA DE CHILE: EL MITO DE LA RESISTENCIA INDÍGENA}

La conquista de Chile ha constituido un caso único en América. A diferencia de los imperios azteca e incaico, que, a pesar de contar con una organización estatal compleja, fueron sometidos rápidamente, y de otros pueblos que por su escaso desarrollo sucumbieron fácilmente al poder castellano, en Chile se nos muestra un estado de guerra intermitente pero muy prolongado entre indígenas y españoles o criollos. Aunque oficialmente la conquista se dio por finalizada en el último tercio del siglo XVI, en el caso concreto de Chile no puede afirmarse categóricamente. Si bien es cierto que se dota de unas estructuras administrativas al territorio anexionado a la Corona, la movilidad continua de la frontera y la inseguridad de los asentamientos hispanos ponen en duda la conclusión de la obra conquistadora, y más aún de la colonizadora. Este estado de inestabilidad no induce, por tanto, a pensar que el territorio chileno fuera ocupado del modo estable que lo fueron otras áreas coloniales.

El cuadro de la conquista chilena que pintaron los cronistas de los siglos XVI y $\mathrm{XVII}{ }^{5}$, que es el que ha trascendido a la historiografía posterior, no ha sido revisa-

\footnotetext{
${ }^{4}$ Ya desde el siglo XVI se ofrecen imágenes de Chile contradictorias que, según G. ANTEI, La invención del Reino de Chile. Gerónimo de Vivar y los primeros cronistas chilenos, I. Caro y Cuervo, Bogotá, 1989 , pp. 34-44, «oscilan entre infierno y paraíso».

${ }^{5}$ Sobre las fuentes de la conquista y colonización de Chile en los siglos XVI y XVII, véase F. ESTEVE Barba, Historiografía indiana, Gredos, Madrid, 1964, pp. 517-554. También F. Valenzuela TorrealBa, Vi-
} 
do hasta hace poco. La literatura coetánea dio a la conquista un carácter épico al recrearse en la resistencia araucana frente a las armas castellanas, para lo que no puso reparos al exceso, impregnándola de un barniz heroico que llega hasta lo fabuloso, donde se exageran los hechos de armas y menudean las muestras de crueldad por parte de los nativos y penalidades sin cuento por la de los castellanos. Como si de una transposición de la Reconquista se tratara ¿acaso no estamos ante una frontera medieval? no faltan las apariciones sobrenaturales: la milagrosa intervención de la Virgen y de Santiago al lado de los españoles en las batallas más notorias certifica una mentalidad en la conquista aún medieval ${ }^{6}$.

La conquista de Chile fue iniciada en 1535 por Diego de Almagro, quien partió de Perú hacia el sur con el ánimo de encontrar las riquezas, el poder o la gloria anhelados por todo adelantado español en las Indias, pero la escasez del botín y las vanas esperanzas de obtener los deseados beneficios en su nueva gobernación de Chile, por una parte, y la fuerte resistencia de los araucanos, por otra, forzaron su temprano regreso a Perú, donde, enfrentado a Pizarro y sus partidarios en las guerras civiles provocadas por las discrepancias derivadas del reparto de las ganancias de la conquista peruana, murió ajusticiado, acabando así la primera tentativa de ocupación. En 1540 se inició con Pedro de Valdivia una segunda fase, con más éxito que la primera al conseguir el extremeño fundar asentamientos al sur del río Bio-Bío, referencia fronteriza durante mucho tiempo ${ }^{7}$, como antes la había sido el río Maule, otrora límite meridional del imperio incaico ${ }^{8}$. A pesar de los avances en la ocupación, tampoco Valdivia escapó a la resistencia araucana: en una rebelión

sión de la conquista de Chile según la crónica (Góngora Marmolejo, Mariño de Lobera y González de Nájera), Ed. Agustinianas, Santiago de Chile, 1986. Las principales fuentes coetáneas que contamos para el conocimiento de los primeros tiempos de la conquista chilena son las Cartas de relación de Valdivia (abarcan el período 1545-1552), las crónicas de Jerónimo de Vivar (comprende hasta 1558), Alonso de Góngora Marmolejo (hasta 1575) y Pedro Mariño de Lobera (hasta 1595), y el poema épico de Alonso de Ercilla La Araucana (primera edición publicada en 1569), además de la numerosa documentación oficial que se generó en este período.

${ }^{6}$ La presencia de Santiago o de la Virgen se recoge en La Araucana de Alonso de Ercilla, en la Crónica del Reino de Chile de Pedro Mariño de Lobera, en la Crónica y relación copiosa y verdadera de los Reinos de Chile de Jerónimo de Vivar, en la Crónica General del Reino de Chile de Diego de Rosales, y en la Historia de Chile de Alonso de Góngora Marmolejo, el cual, para dar cierta verosimilitud a las apariciones, los presenta como «una mujer de Castilla y un hombre en un caballo blanco».

${ }^{7}$ Al Bio-Bío se refieren el carmelita descalzo Antonio Vázquez de Espinosa como «el río que ha dividido la guerra» (A. VÁzQuez de EsPInosA, Descripción del Reino de Chile, I. Blas Cañas, Santiago de Chile, 1986, p. 56) y Luis Tribaldos de Toledo como «el río que ha de ser la raya de la guerra» (L. TRIBALDOS DE TOLEDO, Vista jeneral de las continuadas guerras: difícil conquista del gran Reino, provincias de Chile, I. del Ferrocarril (Col. Historiadores de Chile y documentos relativos a la Historia Nacional, $n .{ }^{\circ} 4$ ) Santiago de Chile, 1864, p. 49).

${ }^{8}$ El dominio inca en Chile llegó a ser seguro hasta el río Maule; hasta el Bio-Bío, al sur, escasamente efectivo. No es de extrañar que, consecuentemente, la dominación española no traspasara con eficacia el Bio-Bío. Hasta el Maule, los españoles apenas encontraron resistencia, pues los habitantes de este área guardaban memoria de su pasado tributario del inca anterior a la llegada de los castellanos; se trataba de cambiar un dominador por otro. Es muy revelador el hecho de que los indígenas peruanos que acompañaban a los españoles en las expediciones que partían del norte hacia Chile, al llegar al Maule volvían las espaldas y regresaban a sus tierras, dando así terminada su misión. Recreaban, de este modo, los tiempos en que eran ellos los dominadores. 
indígena en 1553 fue apresado y torturado hasta morir. La imagen del conquistador extremeño sometido a crueles tormentos por los «temibles» araucanos ha quedado fijada como uno de los iconos de la conquista de América en los que hemos vivido la escuela de hace unas décadas:

«Con una cáscara de almejas de la mar, que ellos llaman pello en su lengua, le cortaron los lagartos de los brazos desde el codo a la muñeca; teniendo espadas, dagas y cuchillos con que podello hacer, no quisieron por dalle mayor martirio, y los comieron asados en su presencia ${ }^{9} »$.

Mil veces repetida en los viejos manuales escolares, esta estampa de la Historia de Chile de Alonso de Góngora Marmolejo ha pesado a la hora de hacer una valoración de la conquista chilena. A la imagen inhumana de los indígenas, que en todas ocasiones ejecutan sus crueldades ${ }^{10}$, también han contribuido otros tantos cronistas, que no han puesto límites en el tremendismo descriptivo:

«Juntaron los bárbaros algunos españoles que habían tomado vivos, a los niños pequeñitos con sus madres y las demás mujeres y a todos despedazaron rabiosamente con grandísima crueldad [...]. A las criaturas las mataban dando con ellas en la pared; a las madres, con otros tormentos más intensos, y a los hombres, empalándolos vivos ${ }^{11}{ }^{\prime}$.

Pero a la vez que se destacó en los indios chilenos su crueldad y belicosidad también se subrayó su valor, además de otros loables atributos. La primera imagen de los araucanos en España vino del poema épico La Araucana, en el que Alonso de Ercilla canta «el valor destas gentes, digno del mayor loor del que yo le podré dar con mis versos» ${ }^{12}$. La misma cualidad destacaba de los araucanos Santiago de Tesillo un siglo después: «rara prerrogativa la del valor, que nos parece bien aun

9 A. Góngora Marmolejo, Historia de todas las cosas que han acaecido en el Reino de Chile y de los que lo han gobernado (1536-1575), Ediciones de la Universidad, Santiago de Chile, 1990, pp. 115-116. Esta obra, concluida en torno a 1575, unos pocos días antes de la muerte del autor, es un relato centrado fundamentalmente en los hechos de armas de momentos tempranos de la conquista de Chile, en la que Alonso de Góngora Marmolejo (1524-1575), que desde Perú pasó a Chile acompañando a Valdivia, participó como militar.

10 A. González de NÁJerA, Desengaño y reparo de la Guerra del Reino de Chile, Andrés Bello, Santiago de Chile, 1971, pp. 53-61. Antiguo soldado de Flandes, Alonso González de Nájera estuvo ocho años en Chile (1598-1607), donde vivió directamente la resistencia de los indios, pues no en vano estuvo al mando de una compañía y encargado del gobierno de varios fuertes. En su obra, concluida en 1614, quiere demostrar que la guerra de Chile ha sido mal concebida, y para «repararla» propone una serie de remedios.

11 P. Mariño de Lobera, Crónica del Reino de Chile, Ed. Universitaria, Santiago de Chile, 1970, p. 54. La versión que conocemos de esta obra se debe al jesuita Bartolomé de Escobar, a quien el capitán Pedro Mariño de Lobera (c. 1520-1584) entregó sus manuscritos para que los rehiciera según su estilo, de manera que el original se vio considerablemente desvirtuado. En la obra prevalece un tono mítico (exagerado número de participantes en los combates, apariciones milagrosas, muestras desmesuradas de la crueldad con la que se emplearon tanto indígenas como españoles) que hace extremar la cautela a la hora de verificar el valor histórico del relato.

${ }_{12}$ ERcilla, A. de, La Araucana, edición a cargo de M. A. Morínigo e I. LeRner, Madrid, 1990, vol. 1, p. 122. 
en los que son enemigos»13. Para Góngora Marmolejo, es «gente bien agestada y la más bien partida que hasta hoy se ha visto en Las Indias» ${ }^{14}$; según Mariño de Lobera, son de «cuerpos fornidos y membrudos, rostros hermosos y colorados, aunque trigueños, de suerte que siempre andan representando alegría, y, consiguientemente, son bien acondicionados y animosos y muy arrojados en las batallas»15; Gónzález de Nájera, por su parte, señala «el singular amor que tienen a su patria» ${ }^{16}$.

El hecho de que frente a los calificativos de crueles, fieros o bárbaros con los que son referidos los indios aparezcan, entre los mismos cronistas, otros que expresan valores humanos de diferente signo, como valientes, esforzados o «patriotas», no es sino la expresión de una misma idea: ha sido recurrente por parte de los vencedores realzar al enemigo para así subrayar los méritos propios. De los aztecas e incas podía destacarse, además de su numerosa población, el grado de civilización para mayor gloria de una misión conquistadora triunfante; no así de los chilenos. En México y Perú encontraron sendos pueblos capaces, en un proceso expansivo, de someter a otros. Si a los españoles les resultó fácil su conquista no lo fue tanto por su potencial conquistador como por la coyuntura que encontraron, aprovechando para la consecución de sus propósitos la alianza de ciertos pueblos tributarios de los grandes imperios, las disputas internas en éstos o el propio sistema religioso y cosmogónico indígena. El caso de Chile es otro, pues estaba poblado por diversas tribus sin una estructura centralizada, sin cohesión y con un nivel de civilización exiguo, entre las que no se encontraba ninguna que tuviera la capacidad de imponerse sobre las otras. ¿Cómo justificar entonces una empresa a la que no se acababa de poner fin? Era preciso recurrir a la magnificación de los araucanos, dotándolos de potenciales que sin duda eran exagerados, para excusarse ante la metrópoli de la dificultad de la ocupación.

A la sobrevaloración de los indígenas chilenos ha contribuido asimismo el hecho de que fuera en Chile precisamente donde se estableciera el primer Ejército profesional de América. Durante el siglo XVI la fuerza militar en las Indias estaba constituida por un ejército vecinal. Cuando existía una eventualidad bélica, los vecinos debían acudir, con las armas de las que cada uno dispusiese, a reunirse bajo las órdenes de un jefe designado por las autoridades. Este sistema, que fue el que imperó hasta que las circunstancias obligaron a cambiarlo, no daba muchas garantías de tranquilidad a las poblaciones ${ }^{17}$. En 1599 se produjo un levantamiento general indígena que destruyó todas las ciudades situadas al sur del Bio-Bío y causó la pérdida de esos territorios. Este incidente puso de manifiesto la ineficacia del

13 S. Tesillo, Restauración del Estado de Arauco, Lima, 1665 [ed. facsímil, Imprenta de la Universidad Central, Quito, 1923].

14 A. Góngora Marmolejo, Historia ..., p. 72.

15 P. Mariño de Lobera, Crónica ..., p. 31.

16 A. GonzÁlez de NÁJera, Desengaño ..., p. 50.

17 Cf. P. Estellé Méndez, «La conquista. Siglo XVI», en Sergio Villalobos et alii, Historia de Chile, Ed. Universitaria, Santiago de Chile, 1982, pp. 105-109. 
sistema, lo que obligó a la creación de una milicia permanente y remunerada ${ }^{18}$. Con la instauración del Ejército profesional, la Corona dio un nuevo planteamiento a la presencia española en Chile. Al financiar en parte la guerra, se liberó a los encomenderos de una pesada carga ${ }^{19}$. Recordemos que, por el carácter privado de la empresa de conquista en las Indias, los encomenderos, estancieros y ciudadanos en general debían tener parte activa en la defensa de las haciendas y poblaciones. Este nuevo diseño de la organización de las fuerzas militares, junto con el establecimiento de una línea fronteriza defendida por varios fuertes, dio más seguridad a los españoles, aunque no evitó las continuadas incursiones de los indios en los dominios españoles.

\section{LOS FUERTES FRONTERIZOS, CENTROS DE ENCUENTRO Y DE INTERCAMBIO}

Dada la inestabilidad de las misiones y de los asentamientos ciudadanos, en gran medida vulnerables a los ataques de los indios levantiscos, los contactos entre los naturales y los españoles se centraban fundamentalmente en los fuertes. Pero es, sobre todo, el carácter castrense de la vida chilena lo que determina que sean los fuertes el espacio físico donde las relaciones entre unos y otros se hagan más manifiestas. Por eso, tratar de la frontera chilena pasa por referirse ineludiblemente a los recintos fortificados fronterizos.

La fijación de las inestables marcas fronterizas se hacía mediante la instalación de diversos puestos donde se asentarían las guarniciones militares ${ }^{20}$. Éste es el cuadro que de ellos pinta González de Nájera:

\footnotetext{
${ }^{18}$ La necesidad de un Ejército permanente se había sugerido antes de esos incidentes, como lo atestigua una carta del marqués de Cañete, virrey del Perú, a Felipe II, fechada el 12 de abril de 1594, dando cuenta de la guerra de Arauco y señalando la necesidad de poner guarnición de un cierto número de soldados pagados por la Real Hacienda: "Costumbre antigua es de los gobernadores de Chile quejarse que no se les socorre con gente, dinero ni ropa y cuando se les envía dicen que todo es malo y poco y que los soldados van desarmados y rotos [...] y luce tan poco lo que se envía y danse tan mala maña con ello que aunque tengo afición y inclinación a aquella tierra me desanima mucho. Asimismo he escrito muchas veces a Su Majestad que convendría poner doscientos o trescientos hombres de presidio en el estado de Arauco, señalándoles sueldo y pagándosele y esto tengo por el principal remedio para que tenga el fin que se desea aquella trabajosa tierra y los pobres naturales questán de paz y los españoles que tantos años ha que no saben ques quietud, la tengan y alguna causa y entiendo que lo del presidio es lo mejor y que lucirá y será más barato que los socorros que de aquí se envían» (En J. T. MEDINA, Colección de documentos inéditos para la historia de Chile, t. 4, Fondo Histórico y Bibliográfico JTM, Santiago de Chile, 1960, pp. 433-434).

${ }^{19} \mathrm{Cf}$. A. JARA, Guerra y sociedad en Chile y otros temas afines, Ed. Universitaria, Santiago de Chile, 1984, pp. 71-72.

${ }^{20}$ De las que nos ocuparemos en el presente trabajo no serán las plazas fuertes situadas en la costa, aquellas a las que Gabriel Guarda se refiere como fortificaciones en vista al enemigo extranjero (ingleses, holandeses y piratas), sino a las internas, erigidas atendiendo al enemigo doméstico, es decir, a los indios chilenos (G. GuARDA, Flandes indiano. Las fortificaciones del Reino de Chile, 1541-1826, Ed. U.C. de Chile, Santiago de Chile, 1990, pp. 182 y ss.). Sobre las ordenanzas que regulaban los presidios y fortalezas en las Indias, véase J. A. CALDERÓN QUIJANO, Las defensas indianas en la 'Recopilación de 1680', CSIC, Sevilla, 1984, especialmente la Ley XXVII de la Recopilación (dada por Felipe IV en Madrid, a 15 de noviembre de 1637), por la «que en Chile pueda haber plazas para Soldados impedidos».
} 
«[...] algunos dos o tres de tapias, como lo es el más principal que es el de Arauco; pero todos los demás son de palizada, quiero decir de unos palos los más derechos que se hallan a mano del sitio donde se fundan con la rustiquez que se cortan, y de grosor indiferente [...]. Los cuales palos vienen a ser las murallas de los fuertes [...]. Tienen algunos destos fuertes por la parte de dentro otra palizada la mitad más baja que la de fuera [...], el cual hueco o vacío de entre la una y la otra se terraplena todo a la redonda de fagina y tierra, de manera que el tal terraplén viene a servir de muralla al fuerte, donde se pasean las rondas y se ponen los convenientes centinelas, y de donde, finalmente, se pelea y está la defensa detrás de los débiles y flacos parapetos ${ }^{21} \gg$.

En la mayoría de las crónicas se reseña, con observaciones en muchos casos pormenorizadas, la disposición, condiciones de habitabilidad y mantenimiento de las plazas fuertes. En todas ellas se insiste en la precariedad. Así, dice Tribaldos de Toledo, «los más de ellos, no han servido de otra cosa que de fundarlos unos gobernadores y deshacerlos otros». Según el oidor Gabriel de Celaya —escribe en 1610 - , los fuertes

«[...] son tan solamente unos corrales de tapias con unos aposentos dentro de ellos, en que se recogen los soldados y algunos de estos fuertes no son de tapias, sino de maderas y empalizadas, con sus chozas, sin que en ellos asista otra gente más que soldados de sueldo de V. M. ${ }^{22}$ ».

Se hace patente en estas descripciones la endeblez de las construcciones, inoperantes en una guerra prolongada y ante unos pueblos obstinadamente reacios a la sujeción a los invasores. Algunos autores, para justificar la fragilidad de tales fábricas, «de poco aparato y ruido», argumentan lo rudimentario del armamento ofensivo indígena, inocuo — según el juicio de Mariño de Lobera- por «no usar los indios de piezas de batir ni de otras máquinas bélicas para derribar murallas»23; ineficaz, además, al parecer de unos soldados que disponían de tácticas militares puestas en práctica con asiduidad en las guerras europeas y de recursos defensivos y ofensivos que les ponían en ventaja respecto a los indios, como artillería, armas de fuego y de acero, caballos e, incluso, perros ${ }^{24}$. Si bien se insiste en la escasa calidad del material de estas construcciones fundamentalmente de madera, con el consiguiente riesgo de incendio ${ }^{25}$, el número tan alto de fuertes que se es-

21 A. González de NÁJera, Desengaño ..., pp. 181-182.

22 Citado en A. JARA, Guerra ..., p. 79.

23 También Jerónimo de Vivar da referencias del escaso potencial ofensivo de los indios, señalando que en las esquinas del recinto fortificado «una pequeña torre baja con sus troneras [...] bastaba para defensa de aquellas gentes» (JERÓNIMO DE VIVAR, Crónica de los reinos de Chile, edición a cargo de A. BARRAL GómEZ, Madrid, 1988, p. 130).

24 Cf. A. JARA, Guerra ..., pp. 72 y 79.

25 Como apunta G. GuARDA, Flandes ..., pp. 187 y 190, sólo a partir de la gran sublevación general que tuvo lugar en 1599, en la que fueron arrasadas importantes poblaciones, se llega a cambiar la madera por otros materiales más consistente, como lo señala la intervención que, al respecto, llevó a cabo el gobernador Francisco Lasso de la Vega, que, en los años treinta del siglo XVII, «quitó esos recelos, reedificándolos de adobe y teja en perfección». 
tablecieron a lo largo de la raya fronteriza revela que no fue poca la atención que se puso en la defensa de la misma ${ }^{26}$.

Pero el papel que jugaron estas guarniciones fue más allá de lo puramente bélico. Por debajo de las tensiones y enfrentamientos asociados por lo general a los puestos militares se tejían relaciones poco dignas de una historia brillante. Los fuertes, y por extensión las fronteras, fueron lugar de encuentro entre españoles e indígenas al actuar como centros de intercambios comerciales ${ }^{27}$. A través de los fuertes los indios adquirían productos desconocidos para ellos, aunque básicos para los españoles, que con el tiempo hicieron necesarios. Alcohol, hierro, armas, vestidos y baratijas fueron los artículos más demandados por los nativos. Por su parte, los españoles se proveían de alimentos y de caballos, tan necesarios en esta guerra fronteriza, por intermedio de los indios. Ambos vieron, más allá de los conflictos bélicos, el provecho mutuo que les podía reportar la permuta de especies. Con el tiempo, ésta daría lugar a un intenso trueque comercial y a un lucrativo negocio que implicó a muchos de los que se establecieron en la frontera.

El análisis de los objetos de intercambio descubre la precariedad en la que vivían los españoles en los puestos fronterizos. En muchas páginas de las crónicas se apunta la falta de alimentos que se sufría en los fuertes como una de las motivaciones que justificaban el trato comercial con los indios. Por encima de la guerra existía la exigencia de aprovisionar la despensa, con frecuencia vacía. Esta necesidad dio lugar a situaciones paradójicas, como la que refiere Tribaldos de Toledo:

«[...] los indios comarcanos que de esto [del mal aprovisionamiento y mantenimiento de los presidios] no están ignorantes se llegan a los hambrientos con color de paz y les ofrecen muchas cosas de comida que aunque sean muy regaladas para quien padece tanta necesidad, serán ambrosía y néctar suavísimos a trueque de armas que le ferian por ella, y con este ardiz desarman nuestras guarniciones y arman las suyas ${ }^{28}$ ".

En el mismo sentido se expresa González de Nájera:

«Y como no osan quitarles los soldados con violencia estas comidas porque no se quejen dellos, y les impidan sus oficiales el gozarlas, toman por partido comerlas en paz con beneplácito de los indios, aunque sea a costa de los españoles [...]. Así sucede desta manera venir a desarmarse de espadas en tales ocasiones gran parte de nuestro campo, hasta hurtarlas unos soldados a otros para el mismo efecto, los que han dado ya las suyas a los indios viendo que es moneda que tan bien corre entre ellos y que les instiga el hambre, y no solamente les dan espadas, pero otras cosas de las que dije arriba [cuchillos, machetes, hachas, dagas, vesti-

26 Según los cálculos de G. GuARDA, Flandes ..., p. 182, Chile contaba con más de 150 fortificaciones, siendo en el Estado de Arauco, la frontera por excelencia, donde se concentraba el mayor número de ellas.

27 Sobre las relaciones comerciales, véase S. ViLLALOBOS, La vida fronteriza en Chile, Mapfre, Madrid, 1992, pp. 297-314.

${ }^{28}$ L. Tribaldos de Toledo, Vista ..., p. 20 
dos, capotillos, capas y otras mil impertinencias], y para tal efecto se andan los indios de rancho en rancho ${ }^{29}$ ».

La incoherencia de esta situación -invasores que proveen de armas a sus enemigos, a la vez que éstos abastecen de alimentos a aquéllos- sólo es comprensible en un mundo marginal como es la frontera. Queda entrevelado, además, el escaso interés que parecían mostrar los representantes de la Monarquía o los que estaban implicados en la defensa de la frontera por poner fin a una situación que, al parecer de la documentación coetánea, era incómoda para la Corona. Una situación que se mantendría largo tiempo, como lo atestigua una carta del gobernador Manso de Velasco al rey fechada en 1739:

«Por este mapa se enterará Vuestra Majestad de que por lo poco respetable de ellas [las plazas fuertes], por razón de la situación en que se hallan construidas, siempre está expuesta esta frontera a las voluntariedades y antojos muy consentidos de los indios, que muchos años ha pudieron estar reducidos a pueblos con poca efusión de sangre, con sólo mil hombres existentes y puntualmente pagados, como lo estaban dos mil en tiempos pasados, si mis antecesores no hubieran antepuesto sus intereses y comercio de ponchos y otras vergonzosas especies, dejando postergado el servicio de Vuestra Majestad y el bien común del reino ${ }^{30}$ ».

\section{LA OTRA CARA DE LA RESISTENCIA INDÍGENA: LOS INDIOS AMIGOS}

La misma naturaleza de la frontera, donde la sujeción a una ley o a un código cívico y moral era tan débil, propició unos comportamientos poco ortodoxos insólitos muchas veces tanto entre los que estaban a un lado como a otro de la raya. Las relaciones entre ambos grupos no siguieron unas pautas muy definidas, sino que se movieron dentro de un espectro muy amplio, dando lugar a actitudes muy diversas: ni todos los indios mostraron la belicosidad que nos han transmitido las crónicas, ni todos los españoles fueron leales a la Corona. Esta gama de comportamientos se extiende, por parte de los españoles, desde el colonizador que puso todo su empeño en llevar la ley de su rey y de su dios a nuevas tierras hasta los que renegaron de su soberano y de su fe, y por parte de los indios, desde los que mostraron una resistencia enérgica al sometimiento a la Corona española hasta los que colaboraron abiertamente con los conquistadores y no dudaron en ayudarles en su lucha contra otros grupos nativos. Son los indios que colaboraron con los españoles, en el lado indígena, y los renegados y cautivos, en el español, los casos extremos de este espectro; son los que, dadas las situaciones peculiares y paradójicas a las que dieron lugar, ilustran mejor la mentalidad de los hombres de frontera. Los primeros representan la otra cara de la resistencia indígena, y los segundos, parafraseando a Germán Vázquez ${ }^{31}$, el reverso de la conquista.

\footnotetext{
${ }^{29}$ A. GonzÁlez de NÁJERA, Desengaño ..., pp. 171-172.

30 Citado en G. Lagos Carmona, Los títulos ..., p. 305. $82-90$

${ }^{31}$ G. VÁZQUeZ ChAMORRO, «El reverso de la conquista: los indianizados», Historia 16, 238 (1996), pp.
} 
El panorama que encontró Castilla a su llegada a América era el de un continente muy fragmentado política y culturalmente. No hay que ver la conquista de las Indias, por tanto, como un enfrentamiento bilateral entre españoles y nativos, sin hacer distinción entre los distintos pueblos que componían la realidad americana. Tampoco se encontró en Chile una homogeneidad étnica y cultural, ni siquiera geográfica. En la estrecha franja — «de la manera de una vaina d'espada angosta y larga»32 - que limitan los Andes y el Pacífico, y acotada al norte por el desierto y al sur por las zonas heladas de Tierra del Fuego, existía una diversidad geográfica que tenía su correspondencia en una pluralidad étnica: puquinas, changos, diaguitas, picunches, mapuches, huilliches, cuncos, pehuenches, puelches, tehuelches, alacalufes, yámanas o patagones son algunos de los pueblos asentados en el territorio chileno ${ }^{33}$. Hay que precisar que los cronistas centran sus impresiones principalmente sobre los araucanos nombre que dieron los españoles a la etnia mapuche por su circunscripción a la región de Arauco, por lo que muchas de las imágenes de los indios llegadas a España nos referimos sobre todo a aquellas que destacaban su belicosidad son imprecisas, pues no todas las tribus, ni siquiera todos los individuos de un mismo grupo, manifestaron tal denuedo en la defensa de su independencia. Carece de sentido pensar en las guerras de Arauco como una disposición consensuada de los diferentes clanes indios contra los invasores, puesto que los araucanos estuvieron, según algunos autores, más cerca del nivel de banda que del de tribu y carecían del concepto de nacionalidad ${ }^{34}$. Esta estructura social hacía difícil la conjunción de todas las fuerzas indígenas con un sentido consciente de unidad frente al invasor. Cuando se producen insurrecciones generales se trata de alianzas circunstanciales que se deshacen luego fácilmente.

Entre las diversas tribus que poblaban Chile existían rivalidades que ya eran tradicionales antes de la llegada de los españoles. Éstos, como en otros ámbitos del imperio español en América, aprovecharon las rencillas para procurarse la ayuda de unos grupos para combatir a otros. La obra Guerras de Chile, causas de su duración y medios para su fin, del cronista del siglo XVII Santiago de Tesillo, aporta, según el estudio de Andrea Ruiz-Esquide ${ }^{35}$, unos datos sorprendentes respecto a las malocas o malones (vocablo que, en un principio, hacía referencia a los ataques por sorpresa que efectuaban las diferentes tribus entre sí, y que luego sirvió para denominar a las incursiones imprevistas de los indios en territorio español y de los españoles en el indígena): en los ataques que partían de los fuertes, el número de in-

32 A. Góngora Marmolejo, Historia ..., p. 71.

33 Cf. T. Rojas Rabiela (dir.), Historia General de América Latina, I: Las sociedades originarias, Ed. Trotta/UNESCO, París, 1999, pp. 446-464 y 496-534.

34 G. Lagos Carmona, Los títulos ..., p. 33. Véase asimismo J. P. Blancpain, Les Araucans et la Frontière dans l'historire du Chili des origines au XIXème siecle: une épopée américaine, Vervuert, Frankfurt am Main, 1990, pp. 22-23, y H. CASANOVA, «El rol del jefe en la sociedad mapuche prehispánica», en Sergio Villalobos et alii, Araucania, Temas de Historia Fronteriza, Universidad de la Frontera, Temuco, 1989, p. 43.

35 A. Ruiz-Esquide FigueroA, Los indios amigos en la frontera araucana, DBAM/C.I. Diego Barros Arana, Santiago de Chile, 1993, pp. 20-21. 
dios enrolados en los destacamentos hispanos es notoriamente superior al de los soldados. A aquéllos, por su actitud colaboracionista, se les llamó indios amigos para así diferenciarlos de los hostiles, a los que se denominó indios de guerra o rebeldes. A lo largo del período colonial fue muy importante la presencia de los amigos al lado de los españoles, una presencia hasta ahora apenas valorada, ensombrecida, quizás, por la figura más llamativa y novelable de los rebeldes ${ }^{36}$.

Las motivaciones que llevaron a los indígenas a enfrentarse a los españoles eran diversas. Según la óptica idealista de ciertos cronistas, les impelía el ánimo natural de no verse sometidos a otro poder, el no desvincularse de una tierra «donde nacieron libres sin conocer sujeción a persona del mundo» ${ }^{37}$. Con estas emotivas palabras, puestas - a la manera del habla de Castilla - en boca de un cacique, aduce Mariño de Lobera la resistencia que encontró Valdivia por parte de los araucanos: «Habiendo nosotros sido libres y todos nuestros antepasados, sin que en todos estos reinos haya memoria de que algún tiempo hayan estado nuestros progenitores sujetos a nadie».

En otros casos, razones más prosaicas alentaban los ataques, como la posibilidad de hacerse con útiles, armamento y diversos despojos de las contiendas, cuando no de prisioneros que podían utilizar como materia de venta y canje o como esclavos. No hay que ignorar, además, el interés de los notables locales por procurarse esposas blancas, tan apreciadas, por el prestigio que representaban, en las sociedades poligámicas chilenas ${ }^{38}$.

Sin embargo, muchos de ellos vieron en las relaciones amistosas con los españoles potenciales ganancias. La cooperación reportaba a los indios amigos beneficios en nada despreciables: podían quedarse en sus tierras, eximirse del trabajo en las encomiendas y de pagar tributos o trabajar en los fuertes a cambio de unas pagas previamente establecidas, según se relacionan en varios documentos. Al mismo tiempo, la alianza con los españoles suponía un instrumento considerablemente provechoso en las rencillas con otros grupos indígenas. Al amparo de los españoles, los indios aliados podían vengarse de sus enemigos y, a la vez, fortalecerse al obtener en las incursiones en las que acompañaban a los castellanos un apreciable botín (armas, caballos y vestidos, además de mujeres y niños que podían vender como esclavos). Tal colaboración hizo que la enemistad entre algunas tribus y clanes perdurase y, subsidiariamente, la relación entre los españoles y los indígenas aliados se estrechase.

36 En las revisiones historiográficas del Chile colonial que se están llevando a cabo en los últimos años los indios amigos están siendo objeto de un estudio más completo. Véase en particular el citado trabajo monográfico de A. RUIZ-ESQUIDE.

37 L. Tribaldos de Toledo, Vista ..., p. 17.

38 Por ser un rasgo tan ajeno a la tradición familiar de la sociedad europea, la poligamia —esa facultad por la que los indios «no tienen tasa ni límites en las mujeres, porque cada uno tiene todas las que puede sustentar» (A. GonZÁlez de NÁJERA, Desengaño ..., p. 46)— atrajo la atención de los españoles, si bien de modos dispares. Mientras unos advertían su perversidad moral, otros reparaban en su componente sexual, un ingrediente que podía dar gusto al desabrido guiso que era la vida en la frontera. 
Por su parte, los españoles encontraron en los indios amigos no sólo aliados en la guerra, sino también mano obra para la construcción y reparación de los fuertes y haciendas, como explica Jerónimo de Quiroga en sus Memorias, a mediados del siglo XVII:

«[Los indios amigos] en la guerra son los primeros a auxiliar a nuestras armas; son los que reparan los primeros golpes [...]; son los que cortan y guardan las avenidas del enemigo [...], y los que pasan los caballos y ganados nadando por los ríos, y pierden sus caballos nadando, y las vidas muchos. Son los que incansablemente acuden a las poblaciones y reedificaciones de las Plazas y Presidios y a sus reparos, y a otras infinitas cosas que ejecutan con más tesón y liberalidad que los españoles ${ }^{39}$ ».

Abundan en las crónicas los testimonios en los que, como éste, se muestra el punto tan alto que alcanzó la participación indígena en servicios encomendados por los españoles, especialmente en los fuertes fronterizos. Ya consideremos el aspecto comercial, ya el bélico, los beneficios que obtenían de estas relaciones los indios amigos y los españoles eran mutuos. De ahí que esta asociación se dé a lo largo de todo el período colonial.

El concurso de amigos al lado de los hispanocriollos evidencia, por otra parte, la fragmentación cultural chilena antes referida y la falta de cohesión entre las diferentes comunidades indígenas. Una visión simplista de las crónicas, al no estimar la heterogeneidad étnica de Chile, lleva a una consideración moral de los indios fuertemente degradante, tratándolos de traidores a su nación, sin reparar en que la consideración que los aborígenes tienen de los españoles no deja de ser semejante de la que pudieran tener de otras comunidades indígenas. La reflexión que hacen los cronistas en este punto es tan absurda como el hipotético planteamiento que pudiera hacer un indígena chileno sobre las guerras entre diferentes naciones europeas como una lucha entre compatriotas; absurda igualmente como el juicio que pudieran hacer sobre los apoyos a un candidato $u$ otro en una guerra dinástica en términos de lealtad y traición. Testimonios como el de Antonio Vázquez de Espinosa, de finales del siglo XVI, siguen esta línea de razonamiento:

«[...] que los indios espías, aunque sean de los mismos enemigos, en sintiendo que había junto para algún fuerte, venía en cubierto a dar aviso al corregidor o cabeza, porque se lo pagaban muy bien dándole un caballo, o vestido, con que avisaba de cuanto intentaban los enemigos que era de mucha importancia a los españoles y así el tal indio espía llegaba al corregidor, o a la cabeza de la ciudad, y le decía señor un aviso te traigo de importancia, hasme dar por él una, o dos pagas, las cuales se le daban sin réplica, ni dilación con gran puntualidad: porque ellos también con la cudicia y certeza de las pagas, eran puntuales en dar aviso de todo, aunque fuese vender a sus padres ${ }^{40}{ }^{\prime}$.

39 Citado en S. Villalobos, La vida fronteriza..., p. 329.

40 A. VÁZQUEZ de EsPINOSA, Descripción ..., p. 65. 
También el capitán González de Nájera ahondó, unos años más tarde, en estos prejuicios. Así, se admira de que entre los indios

«[...] haya parte dellos que de su voluntad, no sólo se contente de pasarse de nuestra parte, pero tan en nuestro favor y ayuda, que negando su misma nación, amigos y parientes, les hagan tan cruel guerra [...]. Y sobre todo, es mucho más considerar que siendo aquella nación de su natural, en todo extrema, falsa y engañosa, sin honra y sin palabra, y tan traidora a los suyos mismos [...], guardándonos tanta lealtad y fe, que con haber habido de nuestra parte destos amigos en nuestra ayuda desde que se comenzó aquella guerra, a tiempos tan grande número dellos que excedía con gran demasía al de nuestros españoles, no se sabe hasta ahora que hayan vuelto las armas contra los nuestros, acompañándolos en la guerra, donde ven cada día mil ocasiones de descuidos en nuestra gente cansada y dormida, confiada en su lealtad, así de noche como de día, entre sus espesos montes de las tierras de guerra, donde podían, muy a su salvo, en un repentino acometimiento, hacer la suerte que quisiesen en los nuestros ${ }^{41}$ ».

La presencia en los fuertes del alto número de indios colaborando con los españoles corrobora, en suma, la existencia de unas relaciones, más pacíficas que beligerantes, que ponen en entredicho la tenaz resistencia araucana que se nos ha hecho ver en la frontera chilena a lo largo de la Edad Moderna.

\section{LA OTRA CARA DE LOS CONQUISTADORES: CAUTIVOS Y RENEGADOS}

En el otro lado, el de los españoles, encontramos muy bien representados en Chile dos figuras que se apartan del prototipo que representa aquel audaz guerrero «entregado al servicio del rey» que llamamos conquistador: el cautivo y el renegado. Ambos conocieron la sociedad indígena desde dentro, pero desde la óptica diferente que confiere el matiz fundamental de la voluntariedad, pues si la convivencia entre los indios de los cautivos es forzada y está en su ánimo salir de tal situación, el renegado la busca voluntariamente. Las dos tipologías disfrutaron en las crónicas chilenas de una atención mayor que en las de otras áreas coloniales. El acento que se pone en destacar la fragilidad del limes y la relajación en el control de la tropa fronteriza nos permite intuir la facilidad que encontrarían los indios para traspasarlo y hacer prisioneros en las filas castellanas, por una parte, y los españoles para desligarse de la Corona, por la otra.

La figura del cautivo perdurará, como símbolo manifiesto de la arraigada naturaleza fronteriza de Chile, hasta bien avanzado el siglo $\mathrm{XIX}^{42}$. En el período

41 A. González de NÁJera, Desengaño ..., pp. 277-278.

42 Cf. L. C. PARENTINI GaYANI, Tipos fronterizos en la Araucanía del siglo XIX: los afuerinos, U.C. Blas Cañas (Col. Documentos de Estudio, n. ${ }^{\circ}$ 34), Santiago de Chile, 1994, pp. 69-70. Los araucanos continuaron, durante el siglo XIX, con la práctica de la toma de cautivos, ahora como una forma de provocación para justificar una rebelión. El ejército, por su parte, seguía haciendo prisioneros a modo de escar- 
que nos ocupa, los casos más notorios de cautiverio fueron los protagonizados por el capitán Francisco Núñez de Pineda y Bascuñán ${ }^{43}$ y el dominico Juan Falcón de los Ángeles. Uno y otro ofrecen dos maneras de vivir el cautiverio que tendrán su reflejo en sendas imágenes de la sociedad aborigen ${ }^{44}$.

En una de las numerosas incursiones de los araucanos en el área del BioBío, el capitán Pineda fue apresado por el toqui Maulicán. El prestigio que reportaba la posesión de prisionero tan ilustre le salvó de morir a manos de otros caciques no tan interesados en su vida. La deferencia en el trato que le dispensaron los mapuches que lo capturaron ha llevado a la consideración de que, más que como prisionero, Pineda fue tratado como un «huésped forzoso»45. Con el ofrecimiento, en vano, de varias mujeres en matrimonio y la participación voluntaria del capitán en las ceremonias indígenas y en las faenas agrícolas intentaron sus captores integrarlo en la sociedad mapuche. Finalmente fue utilizado como objeto de intercambio, como lo fueron otros muchos prisioneros, y liberado a cambio de un cacique preso de los españoles. Sus andanzas entre los indígenas - poco más de siete meses duró su cautiverio- las revivió en el libro, escrito en su vejez, Cautiverio feliz y razón individual de las guerras dilatadas del Reino de Chile, donde nos ofrece una detallada memoria de sus vicisitudes. Se trata de la mejor crónica sobre los indios chilenos escrita por un hispano desde el otro lado del limes.

La cara opuesta del cautiverio la ofrece fray Juan Falcón de los Ángeles, un dominico que fue capturado en la rebelión de 1599 junto a otros ocho frailes, de los cuales dos fueron rescatados y los otros muertos por los mapuches. Al contrario que Pineda, el religioso se vio obligado a realizar las más duras tareas agrícolas y pastoriles que le encomendaron y fue objeto de un trato cruel. En calidad de esclavo pasó por las manos de cuatro caciques, uno de los cuales lo intercambió por un cabecilla indígena prisionero, tras catorce años y medio de cautiverio. El capitán Pineda fue invitado a integrarse voluntariamente; fray Juan fue forzado a la aculturación, para lo que se le compelió, como a la mayoría de los cautivos, a expresarse en lengua mapuche. Esta es la razón por la que, según profiere el dominico, los prisioneros «tienen olvidada la lengua española». Los araucanos entendieron el

miento, para utilizarlos como rehenes en vistas a evitar levantamientos indígenas y para procurar sirvientas o concubinas a los jefes militares. El rapto de niñas y jóvenes era una práctica extendida entre los bandidos, que obtenían con su venta a los caciques, al ejército o a los campesinos ganancias nada despreciables.

${ }_{43}$ Francisco Núñez de Pineda y Bascuñán (1608-1680), hijo del maestre de campo Álvaro Núñez de Pineda, prestigioso militar que gozaba de fama entre los indios, es una fuente de información de primera mano para el conocimiento de la frontera chilena del Seiscientos, pues no en vano vivió la experiencia fronteriza en primera persona, fuera ocupando cargos de mando en algunos presidios, fuera en el cautiverio.

${ }^{44}$ Estas imágenes han sido expuestas por C. LÁZARO ÁvILA, «Las visiones condicionadas de Falcón y Pineda: dos cautivos europeos ante la sociedad americana», en F. DEL PINO y C. LÁZARO (coords.), Visión de los otros y visión de sí mismos, CSIC, Madrid, 1995, pp. 127-139.

45 Ibidem, p. 131. 
valor de la lengua como expresión fundamental de una cultura. Rompiendo esta relación lengua-cultura se cortaba el vínculo con la sociedad madre ${ }^{46}$.

La distinta suerte que corrieron les llevó a hacer divergentes interpretaciones de la realidad indígena y a mostrar imágenes contrarias de los naturales. Si para fray Juan Falcón los indios son «gente tan infiel y tan inhumana, que no tienen modo ni orden de república ni la conservan», para Pineda «no son tan bárbaros como los hacen, ni tan crueles como los pintan ni tan mal inclinados como juzgan los que no han experimentado sus tratos ni los particulares modos de vivir». Si prestamos oídos al dominico, advertiremos un odio desmesurado de los araucanos hacia el cristianismo; sin embargo, para el militar, la fe cristiana fue aceptada por los indios, de tal manera que, incluso, llegó a enseñar varias oraciones a los adolescentes con el beneplácito de sus padres ${ }^{47}$.

Más llamativos que los casos de los cautivos son los de los renegados, aquellos que voluntariamente abandonaban su puesto entre los españoles y se pasaban al lado de los indios, asumiendo sus costumbres y, en algunos casos, sus creencias. La frontera chilena ha sido la que ha proporcionado el mayor número de desertores de la colonización americana, según se colige de las crónicas indianas y de la documentación generada durante este proceso. El número de renegados que pululaban por las fronteras no debió ser exiguo, como deducimos de la observación del capitán Pineda, quien refiere que durante su cautiverio reparó en muchos españoles no cautivos que desde hacía mucho tiempo vivían entre los indios y como los indios.

Las causas para la deserción eran diversas: el sexo, el poder, el progreso profesional, la deshonra, la libertad, la huida de la justicia, el hambre y las necesidades materiales. En cuanto al sexo, los españoles tenían en las comunidades indígenas un acceso más fácil y la posibilidad de disponer de varias mujeres y de gozar de una vida más licenciosa. El soldado Jerónimo Bello —recoge la anécdota González de Nájera ${ }^{48}$ - , preso en el fuerte de La Imperial por su amancebamiento con una mestiza, aprovechó el sitio que los indios estaban sometiendo a la fortificación para pasarse al lado de éstos. Le acompañaron en su deserción un clérigo llamado Joan Barba, que predicaría «contra nuestra fe» entre los indígenas, y la dicha mestiza. Al cabo de los años, los indios les mataron «por delitos que cometieron tocantes a las mujeres, según se ha entendido, por ser celosísimos». Evidente-

46 Esta ruptura era un paso necesario para la efectiva incorporación a las comunidades indígenas de los españoles que capturaban en sus incursiones, especialmente mujeres y niños. Son diversas las referencias que aparecen en las crónicas respecto al interés de los indios por integrarlos en su tribu. Según nos relata el padre Roberto Lagos, en el asedio de Villarrica —recogido asimismo por otros cronistasque duró más de tres años, las mujeres y niños que no encontraron sitio en el fuerte, cuya población se hallaba extenuada por el hambre, fueron capturados e incorporados a la sociedad nativa (Citado en A. NoGGLER, Cuatrocientos años de misión entre los araucanos, s. I., s. i., c. 1972, p. 61).

47 C. LÁZARO ÁVILA, «Las visiones condicionadas...», p. 131. La imagen idílica de los indios que forja el capitán español ha sido recogida por J. ANAdón, Pineda y Bascuñán, defensor del araucano: vida y escritos de un criollo del siglo XVII, Ed. Universitaria, Santiago de Chile, 1977.

48 A. GonzÁlez de NáJera, Desengaño ..., p. 69. 
mente, la promiscuidad tenía entre los araucanos ciertos límites, lo que al parecer no entendieron nuestros renegados, para pérdida de sus vidas.

A los pioneros que habían dejado su tierra natal ante la falta de perspectivas de progreso social y económico, las Indias se presentaban como una aventura incierta pero de provechosas expectativas; sin embargo, la realidad frustró sus sueños de oro y poder. Ante esta realidad, ¿acaso no era tentador para el soldado raso de la insegura frontera pasarse al otro lado, donde podía lograr una posición relevante? Se reseña en las crónicas los casos de algunos mestizos —una condición, la de mestizo, que, salvo raras excepciones, les limitaría en la sociedad española- que llegaron a ser toquis. La misma reflexión cabe hacerse respecto al progreso profesional. Salvo algunos notables conquistadores, que obtuvieron títulos, gobernaciones, encomiendas y dineros, además de fama, el común de los españoles que se establecieron en las Indias no vio mejorada en gran medida su situación. Diego de Rosales cuenta en su Historia General del Reino de Chile el episodio del español Francisco de Almendros, que «habiéndole capturado mozo los indios, se había aplicado a herrero y había ganado mucho con el oficio». Esta circunstancia ya había sido anotada por González de Nájera: Ios indios, cuando tienen prisioneros españoles, «perdonan la vida a los que saben algún oficio, como herreros para forjarles armas $\gg 49$.

La huida de la justicia fue otro factor importante que alentó a hispanocriollos y mestizos a pasarse al otro bando. Es el caso del referido Jerónimo Bello y de otros tantos que vieron en la defección un medio de «redención de sus condenas». Este móvil debió ser uno de los que más temprano empujaron a la deserción, antes de que el pionero se sintiera desengañado por la realidad decepcionante de la frontera, como lo revela la admiración que causaba «a los antiguos pobladores de Chile el ver que haya tanto número de fugitivos entre los indios acordándose que en otro tiempo tenían a gran maravilla haber algún mozuelo mestizo entre ellos huido por algún delito ${ }^{50}$.

El hambre y las necesidades materiales son las motivaciones sobre las que los testimonios son más explícitos. Entre «las más ordinarias causas porque se pasan al enemigo los fugitivos está el desaprovechamiento asiento de los fuertes» ${ }^{51}$, escribe González de Nájera, que justifica así la huida de los fortines:

«Vense descalzos como los indios, tan desnudos como o mal arropados como los indios, que trabajaban más que los indios, y que comen y beben y duermen mucho menos que los indios; y como la desnudez, trabajos y hambres hacen hacer muchas cuentas, en dando en esta de irse a los enemigos, se van a ellos, conociendo que ha de ser entre ellos su suerte mejorada ${ }^{52}$ ».

\footnotetext{
49 Ibidem, p. 54.

50 Ibidem, p. 117.

51 Ibidem, p. 122.

52 Ibidem, p. 192.
} 
Es en este punto donde los cronistas impregnan las plumas con una tinta más intensa y donde menos freno se pone a la efusión de los sentimientos. Aprovechan la dureza de las circunstancias para barnizar los relatos con un tinte de emotividad que les da un tono más literario que real. En todo caso, cuando la privación material llega a ser ingente, una comunidad encuentra razón para eximirse de la vinculación a los principios que la rigen. En la frontera chilena los españoles encontraron ocasiones para ello, como en la ya mencionada del asedio de Villarrica:

«[...] la gente más flaca, como las mujeres y los niños, se caían muertos de hambre, y ya las dejaban irse al enemigo por no verlas morir a sus ojos, y cada una se iba por donde quería, sin obediencia las hijas a las madres y las mujeres a sus maridos, porque la hambre no guardaba respetos a la obediencia, por conservar la vida ${ }^{53}$ ".

Otras veces, los móviles de las deserciones no son únicos, sino que una serie de circunstancias encadenadas, entre las cuales es difícil destacar alguna de ellas como el argumento principal, empujan al sufrido cristiano hacia el otro lado. La precariedad material, el sexo y la libertad se unen en el caso de Dionisio y Sebastián, dos hermanos mulatos - de condición libre el primero y esclavo el segundo- que fueron capturados entre los indios rebelados y sometidos a un exhaustivo interrogatorio por parte de las autoridades coloniales:

«Fueles preguntado: digan y declaren, clara y distintamente, qué causa y ocasión les movió a huirse entre los dichos indios de guerra. Respondió el dicho Dionisio que la causa y ocasión que a él le movió fue que estando por caudillo en el fuerte de Longotoro por orden de don Alonso de Sotomayor, empeñó un arcabuz que tenía a Juan de León, vecino de Angol, por dos botijas de vino y en esta sazón el capitán Andrés Valiente, corregidor de Angol, le apercibió para una maloca que quería hacer a estos coyuntos y pidiéndole al dicho León su arcabuz le respondió lo había deshecho y hecho clavos y que no se lo podía dar y que en ninguna manera le convenía parecer ante el dicho corregidor porque lo había sabido y estaba muy enojado dello y que junto con esto el dicho corregidor le quería quitar una india que tenía en su servicio, del repartimiento de Gregorio de Oña, llamada Elvira e que por gozar de más libertad de la dicha india y de temor del dicho corregidor, por lo que dicho tiene, se determinó a irse. Y el dicho Sebastián dijo que la causa que a él le movió fue que Hernando Ortiz de Algarayu, su amo, le llevó a la ciudad de Santiago y en ella le vendió o le quiso vender y dejándole en ella se vino el dicho Hernando Ortiz a la ciudad de Angol, el cual pocos días después vino tras dél y fue derecho a su casa y le rogó que no le vendiese a persona alguna porque él le serviría muy bien, el cual le respondió que así lo haría y en ese tiempo le dicho al dicho su amo de las viruelas y en el testamento que otorgó y entendió mandábale volviese a la ciudad de Santiago a poder de la persona a quien vendió y por no verse en poder de otro amo y porque su hermano Dionisio le llevó una hija suya a los indios de guerra se fue a ellos ${ }^{54}$ ».

53 Rosales, D. de, Historia General del Reino de Chile, Flandes Indiano, edición a cargo de Alfonso CALderón, Ed. Universitaria, Santiago de Chile, 1969, p. 96.

54 Declaración de dos mulatos que vivían entre los indios rebelados, 27 de diciembre de 1593, en J. T. MedinA, Colección de documentos ..., t. 4, Santiago de Chile, 1960, pp. 382-390. 
Finalmente, los soldados no estarían, en el otro lado, constreñidos a la rígida disciplina militar, y se desatarían el corsé asfixiante de la moralidad europea. Honra, moral y libertad, tres conceptos tan enlazados en la metrópoli, en las comunidades indígenas podían desligarse. Se mostraba el Nuevo Mundo, pues, ideal para el hombre de frontera, aquel aventurero que lejos de su patria podía encontrar los caminos para desembarazarse de la presión que sobre él ejerciera la sociedad de su tiempo. Allí donde no había reglas, liberarse de los prejuicios morales y sociales que imponía la vieja Europa no era difícil.

Para entender el proceder de los pasados — así se les llama a veces- es preciso analizar la tipología del español en América. La frontera chilena, donde las circunstancias impusieron unas condiciones de vida difíciles, suscitó poco entusiasmo en los españoles ${ }^{55}$, sobre todo en los estamentos altos. Sin embargo, era propicia para el hombre inquieto que nada tenía que perder en su patria o mucho que ganar fuera de ella ${ }^{56}$. La actitud del renegado responde al gesto de las gentes desengañadas que creyeron engrandecer a la Monarquía con su esfuerzo y, empero, nada recibieron a cambio. Sintiéndose, por ello, moralmente libres de la obligación de adhesión a su rey y a su nación, emprendieron una inaudita huida que les llevó a buscar lo remoto geográficamente y a una solución radical en un nuevo planteamiento de la existencia.

Otro tipo humano de características propias en el mundo marginal fronterizo es el de las cautivas —las llamadas aindiadas o indias blancas_-, un híbrido entre el cautivo y el renegado en tanto aúnan al mismo tiempo los rasgos de uno y otro. A diferencia de los cautivos varones, las mujeres rechazaron, en muchos casos, la

55 De las dificultades de encontrar tropas para Chile hablan las numerosas misivas que durante el siglo XVI se remitieron desde Perú solicitando socorro para el Reino de Chile. Son muy elocuentes al respecto las cartas del licenciado Castro, que halla «harta contrariedad en la gente holgazana desta tierra [Perú] que todos se querrían estar en esta ciudad comiendo pasteles, y se maravilla cuando pudo encontrar doscientos soldados, ya que los vagabundos y holgazanes procuraron difamar esta jornada, diciendo que quien había de ir a ella pues no iban sino a volver a sus casas» (Carta del licenciado Castro sobre el poco interés de los españoles del Perú para acudir a la guerra de Chile, 8 de enero de 1565, en J. T. MedinA, Colección de documentos inéditos para la historia de Chile, t. 1, Santiago de Chile, 1956, pp. 27-28). No sin trabajo, leemos en la correspondencia de licenciado, pudieron reunirse doscientos hombres entre criados que fueron del marqués de Cañete y del conde de Nieva, que pusieron ventajosas condiciones para servir al rey en Chile, como asegurárseles las plazas de lanzas y arcabuces por dos años y «aunque muriesen en el viaje se les pagaría el salario de los dichos dos años» (Carta del licenciado Castro sobre la partida de Jerónimo Costilla a la cabeza de doscientos hombres en socorro de Chile y problemas de gobierno de este reino, 6 de marzo de 1565, Ibidem, pp. 30-34). Otra de las prerrogativas para animar el reclutamiento de voluntarios para la guerra de Chile era «perdonar en nombre de Vuestra Majestad los delitos que hasta aquí han cometido y ofrecerles buen tratamiento de aquí adelante» (Carta del doctor Melchor de Saravia a S. M. advirtiéndole de las causas de la duración de la guerra, reformas que conviene introducir en la administración y necesidad de nuevos refuerzos militares, 27 de diciembre de 1569, Ibidem, pp. 251-254). Para embarcarse en la arriesgada aventura chilena, pródigas gracias y recompensas era preciso ofrecer a unos soldados que disfrutaban de una vida muelle en Lima, donde, como irónicamente expresa el doctor Saravia, «están sin entender en más que pasear las calles della y donde no son necesarios más que de acompañar al gobernador a misa e a vísperas por el asiento y seguridad que hoy hay en el Perú» (loc. cit.).

56 Sobre la naturaleza de la tropa chilena, véase G. GuARDA, Flandes ..., p. 291; F. VALENZUELA ToRREALBA, Visión ..., pp. 20-50, y J.P. BLANCPAIN, Les Araucans ..., p. 34-42. 
oportunidad de librarse de sus captores y reintegrarse a su comunidad natal cuando se les presentó tal oportunidad. Una actitud extraña, pero comprensible en aquel tiempo y en aquellas circunstancias. En una sociedad como la española de la Edad Moderna, donde la honra tenía una importancia vital, el haber tenido un trato íntimo con los naturales, aunque fuera de manera forzada, suponía un estigma difícil de aceptar. Era tal la degradación en la que se vieron sumidas las cautivas que -nos cuenta González de Nájera - las rescatadas «traían los rostros tapados con las manos, supliendo lo que no podían los cabellos (oblíganlas sus amos a traer cortados los que caen delante del rostro) que en tan justa vergüenza pudieran servirles de velo» ${ }^{57}$. Entre reintegrarse deshonradas a su sociedad originaria y permanecer como cautivas en la indígena, muchas optaron por lo segundo.

No debieron ser pocas las cautivas cristianas en la frontera chilena, pues uno de los móviles de las incursiones de los indígenas en los dominios castellanos era la captura de blancas, que proporcionaban un gran prestigio a los caciques a la par que una útil mano de obra. Muy elocuente sobre la actitud de las aindiadas es la anécdota que recoge Jerónimo de Quiroga en sus Memorias. Se hallaba, cuenta, en un fuerte fronterizo y pasó cerca de él

«[...] una india blanca, y preguntándole si vendía alguna cosa de comer respondió en lengua castellana que sólo andaba paseando, preguntándole quién era dijo que española cautiva y como yo era recién llegado al ejército le dije se quedase pues estaba entre nosotros, y con ninguna razón la pude persuadir, con que diciéndole si era cristiana dijo que sí y que se llamaba doña Ángela. Repliquele que cómo quería condenarse volviendo al barbarismo, y enfadada no quiso hablar más en castellano y se fue retirando. Yo la agarré y llamé a quien me ayudase para Ilevarla al Capitán General: llegó gente y se rieron todos de mi bobería».

Si damos crédito al relato de Quiroga — y hemos de dárselo en tanto él mismo no pone reparos a mostrarse torpe ante sus compañeros-, las chanzas de la soldadesca ante la actitud del bisoño soldado inducen a pensar que la actitud de doña Ángela no debió ser tan excepcional.

\section{CONCLUSIONES: REBELIÓN Y MESTIZAJE}

A la luz de las crónicas, se nos presentan dos imágenes contradictorias de la historia colonial chilena. Una de ellas, revestida de connotaciones épicas al magnificar la lucha entre los indios y los españoles, donde la figura agrandada de los mapuches que la interminable guerra de Arauco había reflejado en la metrópoli se oponía a la de los esforzados soldados castellanos que padecieron en sus carnes y en sus ánimos la resistencia de aquéllos y las condiciones de vida de una tierra inhóspita y lejana. Una imagen, en suma, en la que los hechos de armas han prevalecido sobre cualquier otra consideración. En la otra se destaca la progresiva in-

57 A. GonzÁlez de NÁJERA, Desengaño ..., p. 68. 
tensificación de los contactos culturales y comerciales entre ambos grupos. La primera representación fundamenta la existencia de una frontera que se prolongó por espacio de trescientos años, y la segunda, el proceso de mestizaje que vivió la sociedad chilena a lo largo del período colonial, que no es, al fin y al cabo, sino la confirmación de la permeabilidad de la frontera. A esta imagen polarizada contribuye en cierto modo la adscripción de la autoría de los escritos indianos. Si en los primeros tiempos de la conquista y colonización predominan las crónicas de militares y personal de la administración, posteriormente son las de los misioneros. La diferente óptica de cada uno de ellos dará lugar a interpretaciones también diferentes. Así, la historiografía actual destaca el estado beligerante en los primeros tiempos de la ocupación, atemperándose a medida que la penetración hispana se hace más efectiva, y disponiendo desde mediados del siglo XVII de cada vez más protagonismo las relaciones comerciales y culturales.

La dilatada prolongación en el tiempo de la naturaleza fronteriza de Chile es difícil de entender cuando fue notoria la capacidad de la Monarquía española para sujetar a tantos pueblos - algunos tan complejos como el azteca y el inca- desde el norte de Nueva España hasta el sur del continente. Las guerras de Arauco habían generado tantos gastos a la metrópoli que llevó a cierto cronista del siglo XVII a hacer un paralelismo de la situación chilena con la que padecía la Corona en sus dominios europeos rebeldes; tanto es así que Chile fue llamado el Flandes indiano ${ }^{58}$. En este punto hay que extremar la cautela, pues un análisis riguroso de las fuentes escritas detecta un panorama en cierta manera desvirtuado. La realidad que se hizo ver en la Península fue la de un estado permanente de guerra, que, si bien fue fuente de gastos para una Real Hacienda ya de por sí exhausta, también supuso en sí un lucrativo negocio en el que estaban interesados oficiales, funcionarios, comerciantes y estancieros. Detrás de este cuadro de conflictos incesantes encontramos motivaciones económicas particulares. El estado de guerra justificó en Chile la legalización de la esclavitud de los indios rebeldes ${ }^{59}$, con los consiguientes beneficios que ello podía reportar. Así, la guerra y las acciones contra los indios pretendían en muchos casos no tanto dominar el territorio o someter a los indios como capturar «piezas» para luego venderlas; un estímulo nada desdeñable para enmendar el escaso atractivo que ofrecía Chile a los militares españoles. Al mismo tiempo, los esclavos podían paliar la escasez de mano de obra ${ }^{60}$. Por su parte, los estancieros tenían en el ejército un mercado seguro de sus productos, y los gobernadores y oficiales recibían gran parte de los fondos de la administración

58 Esta expresión se debe a Diego de Rosales, quien así subtituló su Historia General del Reino de Chile para compararla con el Flandes europeo por los costos que generaba a la Corona. Unos gastos que llevaron a sugerir a Felipe III la idea de desistir de la colonización del Chile (Cf. G. GuARDA, Flandes ..., p. XIX).

59 En Real Cédula de 26 de mayo de 1608, Felipe III autorizó «la esclavitud de los araucanos hombres y mujeres mayores de diez años capturados en guerra». Antes de esa fecha son numerosas las cartas remitidas al rey desde Chile en las que se insiste en la utilidad de hacer esclavos a los indios rebelados (Véanse en J. T. MedinA, Colección de documentos ..., t. 5, Santiago de Chile, 1961, passim).

60 Cf. A. BARRAL, Rebeliones indígenas en la América española, Mapfre, Madrid, 1992, pp. 164-165. 
justificando las rebeliones continuas de los indios ${ }^{61}$. El testimonio del monje de Guadalupe Diego de Ocaña es explícito sobre la actitud interesada de los altos cargos de la administración colonial:

«Este desdichado gobernador [Martín García de Loyola], que era más mercader que soldado, había ido a la ciudad de Valdivia, personalmente, a cobrar cierto oro que le debían de mercaderías que tenía allá y también a levantar y apercibir la gente para la guerra ${ }^{62} \gg$.

No sabemos si la dedicación mercantil de don Martín le reportaba más beneficios que la administrativa, pero sí intuimos que le restó un tiempo considerable a sus obligaciones oficiales.

Debajo de la envoltura novelesca con la que los cronistas adornaron reiteradamente sus narraciones —donde esforzados soldados, indios despiadados y traidores, cristianos desleales, nativos aliados, mujeres deshonradas y cautivos irredentos se ven en batallas terribles, persecuciones sin tregua y raptos o padeciendo la crueldad de los enemigos, penurias materiales, hambres y calamidades sin fin- encontramos soterrada una historia más cotidiana, anodina y escasa de emociones en la que indios y españoles se relacionan pacíficamente. La frontera chilena no fue una barrera infranqueable donde se ignoraban o enfrentaban los que estaban a ambos márgenes de la misma, sino un lugar de contacto y de asimilación. De hecho, el proceso de mestizaje que se vive en Chile ya desde el siglo XVI es de tal magnitud que concurre a una situación paradójica en que no se sabe si los hombres que habitan la frontera son, desde el punto de vista cultural, españoles araucanizados o araucanos hispanizados; o, desde el racial, mestizos araucanizados o mestizos hispanizados.

Fueron las propias particularidades de la colonización las que impusieron desde muy temprano la mezcolanza racial. El escaso número de mujeres que se decidieron inicialmente a formar parte de la aventura americana, por una parte, y el atractivo que tenía para los caciques la posesión de mujeres blancas, por otra, crearon situaciones que favorecieron el mestizaje. La primera circunstancia forzó a los

61 Cf. S. Villalobos, «Guerra y paz en la Araucania: periodificación», en S. VILLALobos et alii, Araucania, ..., pp. 14-21. En la documentación oficial indiana encontramos numerosos papeles en los que los altos cargos de la administración colonial solicitan al rey recompensas por los servicios prestados en Chile. Son representativas las misivas del gobernador don Francisco de Quiñones, en las cuales, después de enumerar los buenos servicios prestados y las penalidades sufridas y de insistir en el «notable peligro de sus vidas», solicita y espera del rey ver «duplicada satisfación del gasto de su patrimonio y muy aventajadas mercedes para mí y para mis hijos» (Carta de Francisco de Quiñones al rey destacando los servicios prestados en Chile y solicitando mercedes para él y su familia, 28 de abril de 1601, en J. T. MEDINA, Colección de documentos ..., t. 5, pp. 364-365); solicitudes que son apoyadas por su cuñado el arzobispo de la ciudad de los Reyes (28 de abril de 1601, Ibidem, pp. 361-364) y por don Luis de Velasco, quien intercede por el gobernador en «la causa de un hábito de Santiago que pretende» (2 de mayo de 1601, Ibidem, p. 366) e insiste en la gratificación para éste y su hijo mayor (27 de abril de 1602, Ibidem, pp. 368-370).

62 OcAÑA, D. de, A través de la América del Sur, edición a cargo de Arturo ÁlvareZ, Historia 16 (Crónicas de América, 33), Madrid, 1987, p. 114. 
españoles a buscar la compañía de mujeres indígenas, ya en calidad de barraganas, ya legitimada por la sociedad nativa, como en el caso de los renegados y cautivos que se integraron en las comunidades indias. La segunda animó las numerosas incursiones de los indios en el lado de la frontera dominada por los españoles con el objeto de raptar mujeres blancas. El grado de fusión es tal a mediados del siglo XVII que no pasa desapercibida esta circunstancia a los que recorren la frontera, como manifiestan las palabras del misionero jesuita Juan Bell en su Historia de la Compañía de Jesús en Chile:

«Toda la gente que tiene la parcialidad de Boroa es mestiza; y también blanca como españolas de quien por parte de padre o madre descienden de los muchos cautivos que cogieron cuando se destruyeron las ciudades; y ellos se precian de eso, y aunque tengan, como todos tienen propio nombre de la tierra, conservan el apellido de sus descendientes. A este paraje de Boroa [...] sentaron su habitación nuestros padres en el fuerte que había de españoles. Hallaron los padres mucha y buena disposición en aquella gente, principalmente en aquellos españoles y españolas cautivos; que desde el alzamiento general estaban padeciendo como esclavos en la porfiada guerra de cincuenta años, muchos hijos de éstos se habían multiplicado en tanto espacio de tiempo y bautizado en el cautiverio sin noticias de los misterios de nuestra santa fe, como también muchos indios viejos de los que bautizaron los españoles, y sacerdotes antiguos, que todavía conservaban memorias de lo que se les había enseñado de la doctrina cristiana; pero con muchos errores, abusos y supersticiones ${ }^{63}{ }^{\prime}$.

El mismo sentido siguen las observaciones que hizo, más tarde, el provincial de la Compañía de Jesús, quien en una carta al Virrey del Perú, fechada el 3 de agosto de 1683, dice, refiriéndose a Toltén, que tiene «la gente más bien dispuesta de toda la tierra y donde hay mucha sangre española pues casi todos son mestizos»64. Además del progresivo proceso de mestizaje a lo largo de la Edad Moderna, a partir de mediados del siglo XIX se constata en Chile una importante colonización de su territorio con elementos no exclusivamente españoles. Un conjunto heterogéneo de turcos, asiáticos, dálmatas y, sobre todo, alemanes fue configurando un mosaico cultural variado donde lo puramente indígena no tiene la misma presencia que en otras áreas de la América española. En Chile adquiere pleno sentido la obra del mestizaje y la transculturación como elementos primordiales de la conformación de los pueblos latinoamericanos.

63 Citado en S. Villalobos, La vida fronteriza..., p. 325. Estos errores son un componente más del proceso de sincretismo al que abocó la cohabitación de las creencias indígenas y cristianas. Al introducir en el complejo religioso-espiritual aborigen una serie de conceptos tan ajenos al suyo, hubo que hacer adaptaciones e interpretaciones originales para encajarlos. Indudablemente, no es un hecho exclusivo del ámbito hispano. Jack London, que tan bien ha retratado la frontera polar norteamericana en su obra literaria, al referirse a uno de los personajes de Una destilería hiperbórea —el indio Moosu-, advierte que no tenía más que un defecto: «había adquirido un conocimiento superficial de las Escrituras, durante una temporada que había sido compañero de un renegado canadiense francés que había estudiado para clérigo. Moosu no tenía idea de lo que era el cristianismo, pero tenía la cabeza llena de milagros, batallas y dispensas, de todo lo cual no entendía una sola palabra» (J. LoNDON, 'La peste escarlata' y otros cuentos, Madrid, 1985, p. 69).

64 Citado en S. VILLALoBos, La vida fronteriza..., p. 325. 
Aun siendo la chilena una frontera más entre las muchas que se originaron en el continente, y no la única que planteó problemas a la Corona, las dificultades que se encontraron en su conquista y colonización fueron acometidas de forma original. La combatividad de los mapuches tuvo su equivalente en los chichimecas y apaches en el otro extremo del Imperio ${ }^{65}$, pero en Chile fue abordada con la idea singular y novedosa que fue la creación de un Ejército permanente de frontera. En la Edad Moderna, la tierra chilena aparecía como una frontera cuya línea de avance apenas se movía. Daba así la sensación de que los presidios fronterizos, más que ser una avanzada de los colonizadores, señalaban una línea de contención para proteger el virreinato del Perú de los belicosos indígenas del sur. La escasez de mano de obra -la población chilena estaba formada en un número relativamente alto por soldados - y las propias dificultades de la colonización no permitían un poblamiento efectivo de la tierra ${ }^{66}$. Sin embargo, tales condicionantes no fueron impedimento para que de hecho se produjeran los contactos humanos que devienen inevitablemente de un largo período donde el espacio es compartido por grupos aun antagónicos.

De haber estado Chile en la órbita cultural anglosajona, cuyo epicentro detenta una preponderante capacidad de difusión literaria y cinematográfica, su rica vida fronteriza hubiera llenado, sin duda, un incontable número de páginas impresas y de metros de cinta de celuloide. La condición fronteriza de Chile, siendo tan sugerente y atractiva, si bien ha ocupado cierto espacio en los medios eruditos, no ha trascendido a los ámbitos populares como lo ha hecho la frontera norteamericana, que ha sido, especialmente la del siglo XIX, inspiración incesante y tema recurrente del cine y la literatura.

Digamos, finalmente, que la historia de la conquista y colonización chilenas se está escribiendo todavía. Sobre la historiografía heredada, llena de prejuicios, donde las armas eran las protagonistas, una revisión actual está imponiendo unos planteamientos nuevos donde los contactos pacíficos tienen a la larga más importancia que los bélicos, como acertadamente ha expresado Sergio Villalobos:

«El furor de la lucha inicial no ha dejado ver más que el conflicto mismo [y] no se ha captado que por debajo se tejía una historia prosaica, diaria y sin eventos espectaculares, que ponía en contacto a los protagonistas de un lado y otro. Acercamiento y asimilación a merced de la curiosidad y las necesidades mutuas, que al fin resultaron más poderosas que el ejército de las armas ${ }^{67}{ }$.

65 Los mapuches no fueron los únicos pueblos americanos que se opusieron denodadamente a la conquista y colonización española. Chichimecas, chaqueños, chiriguanos y pampas mostraron un talante igualmente combativo que en algunos aspectos tiene ciertas afinidades con el araucano. Véase al respecto C. LÁzARo ÁvILA, Las fronteras de América y los «Flandes indianos», CSIC (Col. Tierra Nueva y Cielo Nuevo, 35), Madrid, 1997. Sobre el caso concreto de los chichimecas, pp. 55-65.

66 La inquietud que causaban las revueltas indias compelió a ejercer en ocasiones la pacífica actividad de la agricultura «teniendo en una mano el arado y la lanza en la otra» (P. MARIÑO DE LOBERA, Crónica ..., p. 43).

67 S. VilLalobos, La vida fronteriza..., p. 297. 